\title{
ANALISIS EKSPOR DAN PRODUKSI KARET DI INDONESIA (APLIKASI MODEL LAG TERDISTRIBUSI)
}

\author{
Ahmad Soleh \\ Fakultas Ekonomi Universitas Dehasen Bengkulu \\ ahmadsolehse81@yahoo.co.id
}

\begin{abstract}
ABSTRAK
Ahmad Soleh; Analisis Ekspor dan Produksi Karet Di Indonesia (Aplikasi Model Lag Terdistribusi). kontribusi sub-sektor Perkebunan dalam perekonomian Indonesia memiliki peran yang sangat penting. Karet merupakan salah satu komoditas ekspor utama Indonesia. Peningkatan volume ekspor karet Indonesia seiring dengan peningkatan produksi karet dalam negeri. Penelitian ini bertujuan untuk menguji hubungan antara volume produksi dan ekspor karet Indonesia selama periode 2000-2014. Sumber data diperoleh dari laporan Badan Pusat Statistik (BPS). Metode analisis yang digunakan adalah model regresi dengan menggunakan Model Lag Terdistribusi diolah dengan bantuan program Eviews. Adapun penentuan Model Lag Terdistribusi dengan menggunakan kriteria Schwarz (SC) dengan nilai terendah. Hasil penelitian menunjukkan bahwa hubungan antara produksi karet dalam negeri dengan volume ekspor karet di Indonesia sangat tinggi yaitu sebesar 93\%. Koefisien ini menunjukkan bahwa Model Koyck sesuai untuk mempelajari hubungan antara jumlah produksi karet dalam negeri dan volume ekspor karet Indonesia. Dengan menggunakan Schwarz criterion (SC) diperoleh panjang lag adalah 4. Ini berarti bahwa voloume ekspor karet Indonesia dipengaruhi oleh produksi karet dalam negeri dalam kurun waktu empat tahun terakhir. Di sisi lain, menurut Model Koyck, waktu yang dibutuhkan untuk perubahan produksi karet dalam negeri memiliki efek yang signifikan dan terdeteksi pada volume ekspor yaitu 0,5 tahun. Selama periode pengamatan, kenaikan satu ton produksi karet dalam negeri tahun ini akan meningkatkan volume ekspor karet sebesar 0.614898 ton, kenaikan satu ton produksi karet dalam negeri satu tahun sebelumnya akan meningkatkan volume ekspor karet sebesar 0.202631 ton, kenaikan satu ton produksi karet dalam negeri dua tahun sebelumnya akan meningkatkan volume ekspor karet sebesar 0.066774 ton, kenaikan satu ton produksi karet dalam negeri tiga tahun sebelumnya akan meningkatkan volume ekspor karet sebesar 0.022004 ton dan kenaikan satu ton produksi karet dalam negeri empat tahun sebelumnya akan meningkatkan volume ekspor karet sebesar 0.007251 ton. Perhatian pemerintah sangat diperlukan dalam pengembangan produksi karet Indonesia yang dapat dilakukan melalui stabilisasi harga karet dan pengembangan industri pengolahan.
\end{abstract}

\section{ABSTRACT}

Ahmad Soleh; Export Analysis and Production of Rubber in Indonesia (Distributed Lag Model Application). Contributions plantation sub-sector in the Indonesian economy has a very important role. Rubber is one of the leading commodity exports of Indonesia. Indonesia rubber export volume increase along with the increase in domestic rubber production. This study aimed to examine the relationship between the volume of production for Indonesia rubber export during the period 2000-2014. Sources of data obtained from reports the Central Bureau of Statistics (BPS). The analytical method used is the regression model by using a distributed lag models were processed with the help of Eviews program. As for the lag determination is based on the Schwarz criterion (SC) with the lowest value. The results showed that the relationship between the production of rubber in the country with an export volume of rubber in Indonesia is very high at 93\%. Volume Indonesian rubber exports was influenced by the production of rubber in the country within a period of four years. According Koyck model, the time required to change the rubber production in the country has a significant effect and detected in the export volume of 0.5 years. During the observation period, the increase of one tonne of rubber production in the country this year will increase the volume of rubber exports amounted to 0.614898 tons, increase of one tonne of rubber production in the country one year earlier will increase the volume of rubber exports amounted to 0.202631 tons, increase of one tonne of rubber production in the country two years earlier will increase the volume of rubber exports amounted to 0.066774 tons, increase of one tonne of rubber production in the country three years earlier will increase the volume of rubber exports amounted to 0.022004 tons and increase of one tonne of rubber production in the country four years earlier will increase the volume of rubber exports amounted to 0.007251 tons. Government attention is needed in the development of Indonesian rubber production by stabilizing the price of rubber, development and industrial production for processing.

Key Words: Export and Production of Rubber, Indonesia, Koyck Models, Distributed Lag Models 


\section{LATAR BELAKANG}

Indonesia merupakan salah satu negara berkembang yang mengalami perubahan struktur ekonomi sejak era kemerdekaan. Sejak awal era pemerintahan Orde Baru hingga sekarang, dapat dikatakan bahwa telah terjadi proses perubahan struktur ekonomi yang cukup pesat. Pada tahun 1970-an nilai tambah bruto (NTB) dari sektor pertanian, kehutanan dan perikanan menyumbang sekitar $45 \%$ terhadap pembentukan PDB, pada dekade 1990-an menyumbang sekitar 16\% hingga 20\% dan tahun 2014 hanya menyumbang 14,33\%. Sedangkan sumbangan sektor industri pengolahan dalam pembentukan PDB mencapai 23,71\%. Hal ini mencerminkan bahwa ekonomi nasional mengalami perubahan secara struktural dalam 3 dekade belakangan ini. Semakin kecil kontribusi sektor pertanian dalam pembentukan PDB relatif terhadap sektor-sektor ekonomi non primer lainnya, bukan berarti volume di sektor pertanian cenderung menurun. Penurunan tersebut disebabkan oleh laju pertumbuhan output (rata-rata per tahun atau pertumbuhan total) di sektor tersebut relatif lebih rendah dibanding laju pertumbuhan output dari sektor industri pengolahan.

Meskipun kontribusi sektor pertanian, kehutanan dan perikanan terhadap Produk Domestik Bruto (PDB) Indonesia cenderung mengalami penurunan, sektor ini tetap memiliki peran yang sangat penting dalam perekonomian Indonesia. Sebagian besar penduduk Indonesia masih berada di perdesaan dan menggantungkan pendapatannya dari sektor tersebut. Data ststistik menunjukkan bahwa pada Februari 2015, penyerapan tenaga kerja di sektor ini masih sangat tinggi yakni mencapai 40,12 juta orang. Pengembangan sektor ini sangat penting dilakukan mengingat sektor ini memiliki kekayaan sumber daya alam yang beraneka ragam tersebar di seluruh wilayah Indonesia, kaya akan lahan, kesuburan tanah, dan iklim yang mendukung dalam menghasilkan produk pertanian, kehutanan dan perikanan yang berkualitas dan mampu bersaing di pasar bebas.

Tanaman perkebunan yang merupakan sub sektor pertanian, peternakan, perburuan dan jasa pertanian, memberikan kontribusi yang tinggi dalam pembentukan Produk Domestik Bruto (PDB) Indonesia. Tahun 2014, sub sektor ini memberikan kontribusi tertinggi dibanding dengan sub sektor lainnya yakni mencapai 338.154,5 miliar rupiah. Komoditi karet alam adalah salah satu komoditi unggulan sub sektor perkebunan yang menjadi primadona ekspor Indonesia setelah kelapa dan minyak kelapa sawit. Tanaman karet dapat berproduksi sepanjang tahun di Indonesia dan hampir semua daerah di Indonesia cocok untuk ditanami karet (pulau Sumatera merupakan wilayah yang memberikan kontribusi tertinggi dalam produksi karet di Indonesia). Hal tersebut yang menjadikan Indonesia sebagai salah satu negara produsen karet di dunia.

Perkembangan produksi karet di Indonesia cenderung mengalami peningkatan di setiap tahunnya. Rata-rata produksi karet Indonesia tahun 2000-2014 mencapai 1.966,1 ribu ton per tahun. Tahun 2014, produksi karet Indonesia mencapai 2.555,4 ribu ton. Nilai produksi karet juga tidak terlepas dari luas lahan yang tersedia untuk perkebunan karet. Luas lahan perkebunan karet tahun 2014 tercatat seluas 543.300 ha. Peningkatan produksi karet ini menjadi potensi bagi Indonesia untuk melakukan perdagangan luar negeri. Tingginya ekspor karet memberi kontribusi bagi penerimaan negara Indonesia. Tiga negara tujuan ekspor karet terbesar adalah Amerika Serikat, Jepang dan Tiongkok. Tahun 2014, nilai volume ekspor ke negara masing-masing secara berturut-turut adalah 571.200 ton, 401.600 ton, dan 357.800 ton. Sedangkan untuk wilayah negara ASEAN, Singapura merupakan negara tujuan ekspor karet terbesar jika dibanding dengan negara ASEAN lainnya yakni mencapai 14.200 ton.

Terdapat beberapa faktor penentu ekspor karet Indonesia diantaranya adalah produksi karet dalam negeri, jumlah konsumsi/penggunaan karet dalam negeri, stok tahun sebelumnya, nilai tukar uang, volume ekspor periode waktu sebelumnya, kebijakan pemerintah, harga ekspor periode waktu $t$, dan harga domestik negara tujuan. Perekonomian dunia memberi dampak pada perlambatan ekonomi Indonesia, khususnya perekonomian negara tujuan ekspor karet Indonesia. Penurunan harga karet dalam kurun waktu yang relatif lama dapat berdampak pada penurunan produksi karet dalam negeri dan penurunan produksi karet dalam negeri akan mempengaruhi volume ekspor ke luar negeri. Berdasar pada latar belakang di atas, Penulis bertujuan untuk mempelajari volume ekspor karet dan hubungannya dengan produksi karet di Indonesia dengan menggunakan Model Koyck. Penulis mengukur sensitivitas volume ekspor dengan produksi karet dan membangun interaksi antara volume ekspor dan produksi karet melalui Model Lag Terdistribusi.

\section{LANDASAN TEORI}

\section{Teori Perdagangan Internasional}

Ekonomi internasional diartikan sebagai bagian dari ilmu ekonomi yang mempelajari dan menganalisis tentang transaksi dan permasalahan ekonomi internasional yang meliputi perdagangan, keuangan dan organisasi, serta kerjasama ekonomi antarnegara. Kebijaksanaan ekonomi internasional 
dilakukan untuk mencapai tujuan utama yaitu untuk meningkatkan kesejahteraan masyarakat. Tujuan lain adalah untuk mengusahakan tercapainya keseimbangan neraca pembayaran dan tujuan pembangunan ekonomi (Deliarnov, 1995). Melalui spesialisi dan perdagangan dapat meningkatkan kesejahteraan masyarakat di beberapa Negara. Sejak beberapa abad yang lalu, ahli-ahli ekonomi telah telah mengemukakan berbagai pandangan yang menerangkan tentang berbagai kebaikan perdagangan. Empat kebaikan perdagangan menurut Sukirno (2011) yaitu (1) dapat memperoleh barang yang tidak dihasilkan di luar negeri, (2) meningkatkan kesejahteraan masyarakat melalui spesialisasi, (3) memperluas pasaran barang-barang domestic, (4) memperoleh barang modal yang lebih baik, dana modal yang lebih banyak, dan tenaga kerja serta kepakaran yang lebih baik dari negara lain.

Keuntungan dari spesialisasi merupakan faktor yang paling utama yang menerangkan sebebnya negara melakukan perdagangan. Walaupun berbagai negara dapat menghasilkan barang yang sejenis, perdagangan yang menguntungkan semua pihak yang melakukan perdagangan dapat diwujudkan. Melalui perdagangan, kemakmuran dunia dapat ditingkatkan dan setiap negara menikmati barang yang lebih banyak. Keuntungan dari spesialisasi dan perdagangan tidak selalu didistribusikan secara seimbang diantara negara yang melakukan perdagangan. Dalam jangka pendek hal tersebut ditentukan oleh harga pertukaran dalam perdagangan. Suatu negara memperoleh keuntungan yang lebih besar dari perdagangan apabila harga pertukaran yang diekspornya mendekati harga yang berlaku di negara lain. Keuntungan yang diperolehnya semakin terbatas apabila harga pertukaran mendekati harga relatif di dalam negeri. Dalam jangka panjang, keuntungan perdagangan ditentukan oleh syarat perdagangan. Jika syarat perdagangan semakin baik yaitu harga barang ekspor mengalami kenaikan yang lebih cepat dari harga barang impor, keuntungan dari perdagangan semakin besar. Akan tetapi apabila harga impor mengalami kenaikan yang lebih cepat dari harga impor keuntungan dari perdagangan semakin rendah.

\section{Teori Permintaan}

Teori permintaan menerangkan tentang sifat permintaan para pembeli terhadap sesuatu barang (Sukirno, 2012). Pemintaan merupakan jumlah yang diminta atas suatu komoditas pada tingkat harga dan periode waktu tertentu. Permintaan suatu komoditas merupakan hubungan yang menyeluruh antara kuantitas komoditas yang akan dibeli konsumen selama periode tertentu pada suatu tingkat harga. Produksi dalam negeri diperuntukkan bagi pemenuhan kebutuhan masyarakat negara setempat, namun dalam kondisi produksi berlebih makan akan mendorong terjadinya ekspor. Ekspor suatu negara adalah kelebihan penawaran domestik setelah dikurnagi permintaan domestik atau konsumsi ditambah dengan stok tahun sebelumnya (Salvatore dalam Hendratno, 2008). Fingsi ekspor dapat dirumuskan sebagai berikut:

$\mathrm{X}_{\mathrm{t}}=\mathrm{Q}_{\mathrm{t}}-\mathrm{C}_{\mathrm{t}}+\mathrm{S}_{\mathrm{t}-1}$

Dimana:

$\mathrm{X}_{\mathrm{t}} \quad=$ Jumlah ekspor komoditas tahun $\mathrm{t}$

$\mathrm{Q}_{\mathrm{t}} \quad=$ Jumlah produksi domestik tahun $\mathrm{t}$

$\mathrm{C}_{\mathrm{t}} \quad=$ Jumlah konsumsi domestik tahun $\mathrm{t}$

$\mathrm{S}_{\mathrm{t}-1} \quad=$ Stok tahun sebelumnya $(\mathrm{t}-1)$

Permintaan ekspor ialah permintaan pasar internasional terhadap komoditas yang dihasilkan oleh suatu negara. Permintaan ekspor adalah permintaan pasar internasional atau negara tertentu terhadap suatu komoditi. Teori permintaan ekspor bertujuan untuk menentukan faktor-faktor yang mempengaruhi permintaan ekspor suatu negara. Permintaan ekspor suatu negara terhadap suatu komoditi dipengaruhi oleh beberapa faktor. Faktor-faktor yang mempengaruhi permintaan ekspor suatu negara ialah harga domestik negara tujuan ekspor $\left(\mathrm{PD}_{\mathrm{t}}\right)$, harga impor negara tujuan ekspor $\left(\mathrm{PI}_{\mathrm{t}}\right)$ dan GDP per kapita negara tujuan ekspor. Secara keseluruhan fungsi permintaan ekspor suatu komoditas dapat dirumuskan sebagai berikut: $P X_{t}=f\left(P D_{t}, P I_{t}, G_{t}\right)$

Permintaan ekspor juga dipengaruhi oleh faktor-faktor luar negeri yaitu harga di pasar internasional atau harga ekspor $\left(\mathrm{PX}_{\mathrm{t}}\right)$, nilai tukar uang efektif $\left(\mathrm{ER}_{\mathrm{t}}\right)$, dan kebijakan menyangkut impor suatu komoditi sebagai dummy $\left(\mathrm{D}_{\mathrm{t}}\right)$. Pengaruh jangka panjang dalam kegiatan ekspor diketahui dengan memasukkan peubah lag yaitu volume ekspor tahun sebelumnya $\left(\mathrm{X}_{\mathrm{t}-1}\right)$. Secara keseluruhan fungsi ekspor suatu komoditas adalah:

$X_{t}=f\left(P D_{t}, P I_{t}, G_{t}, P X_{t}, E R_{t}, X_{t-1,}, P O P_{t}, D_{t}\right)$

Dimana:

$X_{t} \quad=$ volume ekspor periode waktu $\mathrm{t}$

$P D_{t} \quad=$ harga domestik negara tujuan ekspor periode tahun $\mathrm{t}$

$P I_{t} \quad=$ harga impor negara tujuan ekspor periode tahun $\mathrm{t}$ 
$G_{t} \quad=$ pendapatan perkapita penduduk negara tujuan ekspor periode waktu $\mathrm{t}$

$P X_{t} \quad=$ harga ekspor periode waktu $\mathrm{t}$

$E R_{t} \quad=$ nilai tukar uang efektif periode waktu $\mathrm{t}$

$X_{t-1} \quad=$ volume ekspor periode waktu sebelumnya.

$P O P_{t} \quad=$ Jumlah penduduk periode waktu $\mathrm{t}$

$D_{t} \quad=$ dummy kebijakan impor suatu komoditi

\section{Pengukuran Variabel}

Analisis Regresi

Regresi sederhana adalah hubungan antara peubah bebas (independent) dengan peubah tak bebas (dependent) dan bila hubungannya lebih dari satu peubah bebas disebut dengan regresi berganda.

Model Regresi Sederhana yaitu garis lurus sebagai berikut:

$y_{i j}=\alpha+\beta x_{i}+\varepsilon_{i j}$

Dimana:

$\alpha, \beta$ adalah parameter koefisien regresi

$x=$ peubah bebas

$y=$ peubah tak bebas

$\varepsilon=$ galat

\section{Analisis Regresi Berganda}

Metode Ordinary Least Square Estimator (OLSE) dan Maksimum Likelihood Estimator (MLE) menghasilkan penaksir yang identik dibawah asumsi normalitas $e_{i} \sim N\left(0, \sigma^{2}\right)$. Penaksir $\beta$ dengan sendirinya terdistribusi secara normal dan rata-rata sama dengan $\mathrm{b}$ dan variansi mengikuti distribusi $\chi^{2}=(N-K) \sigma_{s}^{2} / \sigma^{2}$. Distribusi t dapat digunakan untuk menentukan interval keyakinan sebagai uji hipotesis statistik tentang koefisien regresi. Distribusi $\mathrm{F}$ digunakan untuk menguji signifikansi penambahan atau pengurangan peubah bebas (x).

Bentuk umum regresi berganda

$$
\hat{y}=b_{0}+b_{1} x_{1}+b_{2} x_{2}+\ldots .+b_{k} x_{k}
$$

\section{Model Lag Terdistribusi}

Model regresi yang menunjukkan hubungan antara variabel terikat dan variabel bebas yang tersebar atau didistribusikan berdasarkan periode waktu tertentu biasa disebut dengan Model Lag Terdistribusi. Model Lag Terdistribusi atau Infinite Lag Models, dapat ditulis sebagai berikut:

$Y_{t}=\alpha+\beta_{0} X_{t}+\beta_{1} X_{t-1}+\beta_{2} X_{t-2}+\ldots+\varepsilon_{t}$

Model ini menggambarkan bahwa nilai $Y_{t}$ tergantung atau dipengaruhi oleh nilai $X$ pada saat $t\left(X_{t}\right)$, nilai $X$ pada satu unit ukuran waktu sebelumnya $\left(X_{t-1}\right)$, dan nilai $X$ pada dua unit ukuran waktu sebelumnya $\left(X_{t-2}\right)$ dan seterusnya. Selain itu model ini dipengaruhi oleh faktor-faktor lain yang diwakili oleh $\varepsilon$ (Lains, 2006). Model Lag Terdistribusi telah menunjukkan kegunaan yang sangat besar dalam ilmu ekonomi empiris karena model ini telah membuat teori ekonomi yang bersifat statis menjadi yang bersifat dinamis dengan memperhitungkan secara eksplisit peranan dari waktu. Model ini membedakan antara respon jangka pendek dan jangka panjang dari variabel terikat terhadap satu unit perubahan dalam nilai variabel yang menjelaskan.

\section{Transformasi Koyck (Koyck Transformation)}

Koyck (1954) mengusulkan suatu metode penaksiran Model Lag Terdistribusi didasarkan pada asumsi bahwa koefisien $\beta$ menurun secara eksponensial dari waktu ke waktu (Ravines et al., 2003), yaitu :

$$
\beta_{k}=\beta_{0} \lambda^{k}, \mathrm{k}=0,1,2, \ldots . \text { dan } 0<\lambda<1
$$

dimana $\lambda$ adalah tingkat penurunan dari lag terdistribusi (rate of decay of the distributed lag). Adapun asumsi-asumsi dari aturan Koyck (Nachrowi, 2005) yaitu: 
1) Nilai $\lambda$ non-negatif sehingga $\beta_{k}$ selalu mempunyai tanda yang sama

2) $\lambda<1$ maka bobot $\beta_{k}$ semakin kecil semakin jauh periodenya

3) Aturan Koyck menjamin bahwa jumlah $\beta$ adalah penjumlahan jangka panjang, yaitu

$$
\sum_{k=0}^{\infty} \beta_{k}=\frac{\beta_{0}}{1-\lambda}
$$

\section{PENELITIAN TERDAHULU}

Kajian determinan ekspor karet di Indonesia telah dilakukan oleh beberapa peneliti terdahulu dengan menggunakan pendekatan dan hasil yang beragam diantaranya adalah penelitian yang dilakukan oleh Siburian (2012) dengan judul penelitian analisis faktor-faktor yang mempengaruhi ekspor karet alam Indonesia ke Singapura tahun 1980-2010. Metode analisis yang digunakan adalah error correction model (ECM). Hasil penelitian menunjukkan bahwa dalam jangka pendek GDP Singapura memiliki hubungan yang positif terhadap ekspor karet alam Indonesia ke Singapura dan dalam jangka panjang GDP memiliki hubungan yang negatif. Harga karet alam Indonesia memiliki hubungan yang negatif terhadap ekspor karet alam Indonesia ke Singapura baik dalam jangka pendek maupun dalam jangka panjang. Produksi karet alam Indonesia memiliki hubungan yang positif terhadap ekspor karet alam Indonesia ke Singapura baik dalam jangka pendek maupun dalam jangka panjang. Setyawati, et. Al. (2014) menganalisis permintaan ekspor karet alam Indonesia ke Amerika Serikat dengan menggunakan data sekunder tahun 1990-2011. Dengan menggunakan metode regresi berganda menunjukkan bahwa variabel yang memiliki pengaruh terhadap karet alam Indonesia ke Amerika Serikat adalah kuantitas perdagangan, harga karet alam, harga karet alam pada tahun sebelumnya, harga karet sintetis, dan nilai tukar.

\section{KERANGKA TEORITIS}

Distributed lag models menggambarkan bahwa nilai $Y_{t}$ (ekspor karet Indonesia) tergantung atau dipengaruhi oleh nilai $X$ (produksi karet dalam negeri) pada saat $t\left(X_{t}\right)$, nilai $X$ pada satu unit ukuran waktu sebelumnya $\left(X_{t-1}\right)$, dan nilai $X$ pada dua unit ukuran waktu sebelumnya $\left(X_{t-2}\right)$ dan seterusnya. Distributed lag models memperhitungkan tidak hanya nilai tahun ini, tetapi juga nilai-nilai tahun sebelumnya. Distributed lag models terdiri atas infinite lag model dimana variabel tidak dijelaskan sehingga:

$Y_{t}=\alpha+\beta_{0} X_{t}+\beta_{1} X_{t-1}+\beta_{2} X_{t-2}+\ldots+u_{t}$

Di sisi lain, jika beberapa tahun didefinisikan sebagai $k$ untuk mendefinisikan variabel, maka disebut finite distributed lag model, sebelum $\mathrm{u}_{\mathrm{t}}$ dengan menambahkan $\beta_{\mathrm{k}} \mathrm{X}_{\mathrm{t}-\mathrm{k}}$ dan Dalam model ini, variabel dependen $\mathrm{Y}$ $\left(\mathrm{Y}_{\mathrm{t}} \ldots \mathrm{Y}_{\mathrm{t}-\mathrm{k}}\right)$ tidak hanya dipengaruhi oleh nilai hari ini $\left(\mathrm{X}_{\mathrm{t}}\right)$ tetapi juga oleh nilai-nilai masa lalu $\left(\mathrm{X}_{\mathrm{t}-1} \ldots \ldots . . . \mathrm{X}_{\mathrm{t}-\mathrm{k}}\right)$ sehingga modelnya menjadi:

$Y_{t}=\alpha+\beta_{0} X_{t}+\beta_{1} X_{t-1}+\beta_{2} X_{t-2}+\ldots+\beta_{k} X_{t-k}+u_{t}$

Untuk mendapatkan Koyck Model, diasumsikan bahwa dalam infinitely distributed lag models memiliki tanda-tanda yang sama dan geometris menurun seperti berikut:

$\beta_{k}=\beta_{0} \lambda^{k} \quad k=0,1, \ldots$

Dalam Koyck model, interval $\lambda$ adalah $0,1 . \beta \mathrm{k}$ adalah koefisien lag. Koefisien lag $\beta \mathrm{k}$ ) bervariasi dengan $\lambda$ serta oleh $\beta 0$. Nilai-nilai $\lambda$ mendekati 1 berarti bahwa nilai-nilai mendefinisikan variabel di masa lalu jauh memiliki pengaruh yang signifikan terhadap variabel dependen, dan nilai-nilai $\lambda$ mendekati nol berarti bahwa nilai-nilai dari variabel yang menentukan dalam masa lalu cepat kehilangan efeknya variabel dependen. Berarti jumlah lag adalah rata-rata tertimbang;

Mean lag Number $=\frac{2}{1-\lambda}$

Dari persamaan (1), substitusikan $\beta_{1}$ dengan $\beta_{0} \lambda$; subtitusikan $\beta_{2}$ dengan $\beta_{0} \lambda^{2}$; dan seterusnya. Model yang lag terbatas dibentuk menggunakan metode OLS seperti yang ditunjukkan pada persamaan berikut: $\mathrm{Y}_{\mathrm{t}}=\alpha+\beta_{0} \mathrm{X}_{\mathrm{t}}+\beta_{0} \lambda \mathrm{X}_{\mathrm{t}-1}+\beta_{0} \lambda^{2} \mathrm{X}_{\mathrm{t}-2}+\ldots .+\mathrm{u}_{\mathrm{t}}$

Pada persamaan (5) memiliki terbatas lag dan koefisien $\lambda$ tidak linear. Untuk mengatasi masalah ini, maka dikembangkan persamaan dimana $\mathrm{Y}_{\mathrm{t}}$ menjadi $\mathrm{Y}_{\mathrm{t}-1}, \mathrm{X}_{\mathrm{t}}$ menjadi $\mathrm{X}_{\mathrm{t}-1}, \mathrm{X}_{\mathrm{t}-1}$ menjadi $\mathrm{X}_{\mathrm{t}-2}, \mathrm{X}_{\mathrm{t}-2}$ menjadi $\mathrm{X}_{\mathrm{t}-3}$ dan $\mathrm{u}_{\mathrm{t}}$ menjadi $u_{t-1}$ yang ditunjukkan pada persamaan berikut: 
$\mathrm{Y}_{\mathrm{t}-1}=\alpha+\beta_{0} \mathrm{X}_{\mathrm{t}-1}+\beta_{0} \lambda \mathrm{X}_{\mathrm{t}-2}+\beta_{0} \lambda^{2} \mathrm{X}_{\mathrm{t}-3}+\ldots .+\mathrm{u}_{\mathrm{t}-1}$

Selanjutnya dari persamaan (6) dikalikan dengan $\lambda$ sehingga diperoleh persamaan:

$\lambda \mathrm{Y}_{\mathrm{t}-1}=\lambda_{\mathrm{a}}+\lambda \beta_{0} \mathrm{X}_{\mathrm{t}-1}+\lambda^{2} \beta_{0} \mathrm{X}_{\mathrm{t}-2}+\lambda^{3} \beta_{0} \mathrm{X}_{\mathrm{t}-3}+\ldots+\lambda \mathrm{ut}_{\mathrm{t}-1}$

Dari persamaan (7) selanjutnya dikurangkan dengan persamaan (5) sehingga diperoleh:

$\mathrm{Y}_{\mathrm{t}}-\lambda \mathrm{Y}_{\mathrm{t}-1}=\alpha(1-\lambda)+\beta_{0} \mathrm{X}_{\mathrm{t}}+\left(\mathrm{u}_{\mathrm{t}}-\mathrm{u}_{\mathrm{t}-1}\right)$

Dari persamaan (8) pindahkan $\lambda \mathrm{Y}_{\mathrm{t}-1}$ ke ruas kanan, dan $\mathrm{u}_{\mathrm{t}}-\mathrm{u}_{\mathrm{t}-1}$ menjadi $\mathrm{v}_{\mathrm{t}}$ sehingga diperoleh persamaan:

$\mathrm{Y}_{\mathrm{t}}=\alpha(1-\lambda)+\beta_{0} \mathrm{X}_{\mathrm{t}}+\lambda \mathrm{Y}_{\mathrm{t}-1}+\mathrm{v}_{\mathrm{t}}$

Distributed lag model untuk volume ekspor karet Indonesia adalah :

$\mathrm{Q}_{\mathrm{t}}=\alpha+\beta 0 \mathrm{P}_{\mathrm{t}}+\beta_{1} \mathrm{P}_{\mathrm{t}-1}+\beta_{2} \mathrm{P}_{\mathrm{t}-2}+\ldots \ldots \ldots+\beta_{\mathrm{k}} \mathrm{P}_{\mathrm{t}-\mathrm{k}}+\mathrm{u}_{\mathrm{t}}$

Keterangan:

$\mathrm{Q}_{\mathrm{t}} \quad=$ Volume ekspor karet periode $\mathrm{t}$ (ribu ton)

$\mathrm{P}_{\mathrm{t}} \quad=$ produksi karet di periode $\mathrm{t}$ (ribu ton)

Dengan menggunakan kriteria Schwarz:

$\mathrm{SC}=\ln \sigma^{2}+\mathrm{m} \ln \mathrm{n}$

Keterangan:

$\sigma 2=$ Probabilitas perkiraan tertinggi $\sigma 2=(\mathrm{KKT} / \mathrm{n})$

$\mathrm{m} \quad$ = Panjang lag

$\mathrm{n} \quad=$ Jumlah observasi

\section{KERANGKA ANALISIS}

\begin{tabular}{|c|c|}
$\begin{array}{c}\text { Produksi Karet } \\
\text { Indonesia }\end{array}$ & $\begin{array}{c}\text { Volume Ekspor Karet } \\
\text { Indonesia }\end{array}$ \\
\cline { 2 - 3 }
\end{tabular}

Gambar 1. Kerangka Analisis

\section{METODOLOGI}

Penelitian ini merupakan penelitian deskriptif karena mengambarkan objek yang diteliti yaitu volume ekspor dan produksi karet di Indonesia. Penelitian ini juga tergolong sebagai penelitian eksplanatory karena menguji hubungan antar variabel (variabel bebas dan variabel terikat). Penelitian ini menggunakan data sekunder berupa volume ekspor (ribu ton) dan produksi karet (ribu ton) di Indonesia tahun 2000-2014 yang diperoleh dari Badan Pusat Statistik (BPS). Metode analisis yang digunakan adalah model regresi dengan menggunakan pendekatan distributed lag models yang diolah dengan menggunakan bantuan program Eviews. Sedangkan untuk penentuan lag didasarkan pada Schwarz criterion (SC) dengan nilai terendah.

\section{HASIL DAN PEMBAHASAN}

\section{Produksi Karet Indonesia}

Karet merupakan salah satu komoditas ekspor andalan Indonesia. Trend produksi karet cenderung mengalami peningkatan di setiap tahun (gambar 1). Rata-rata produksi karet Indonesia tahun 2000-2014 mencapai 1.966.100 ton. Wilayah yang memberikan kontribusi tertinggi dalam produksi karet di Indonesia adalah pulau Sumatera. Tiga provinsi dengan hasil produksi karet terbesar di pulau Sumatera masing-masing adalah provinsi Sumatera Selatan, Sumatera Utara, dan Riau. Tingginya produksi karet di wilayah ini tidak terlepas dari ketersediaan lahan perkebunan dan kondisi geografis yang mendukung. Gambar di bawah ini menunjukkan perkembangan produksi karet di Indonesia (ribu ton) periode tahun 2000-2014. 
Gambar 1. Produksi Karet Indonesia (ribu ton) Tahun 2000-2014

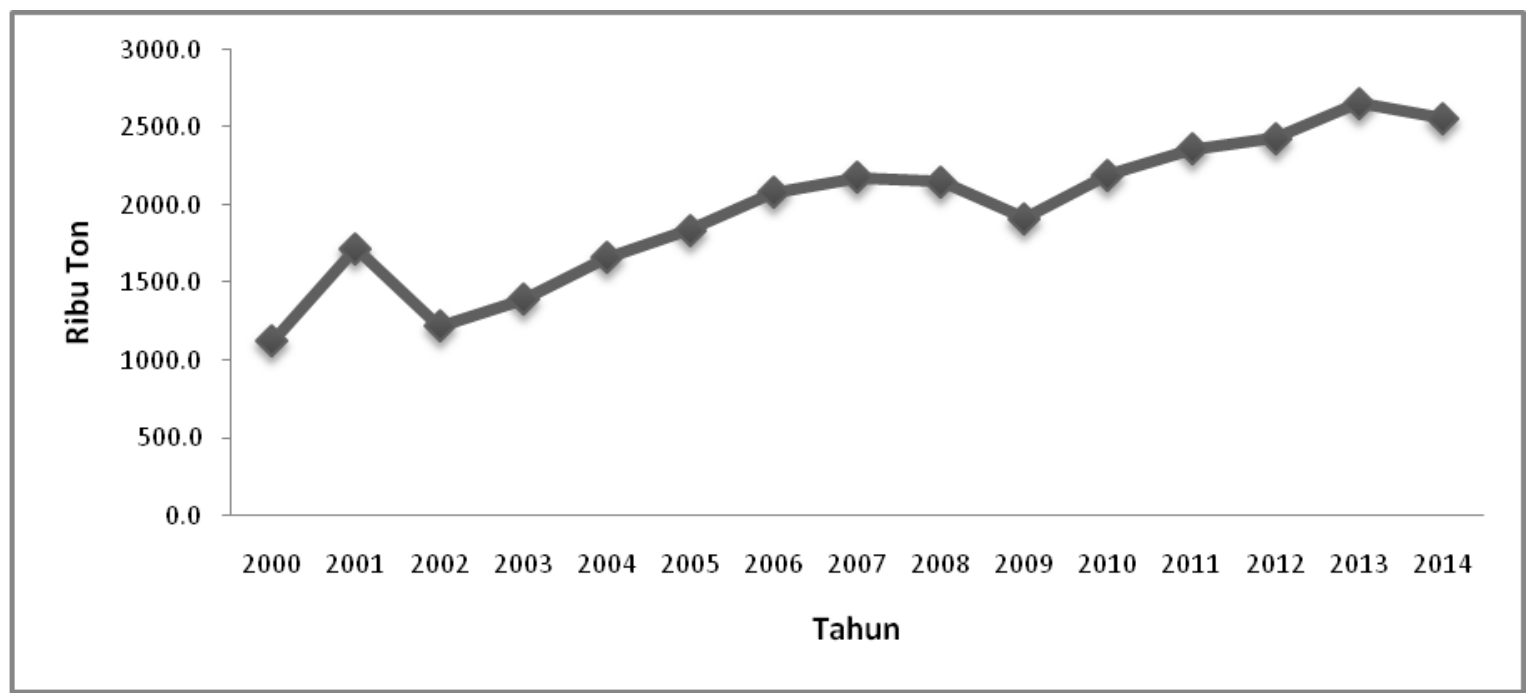

Sumber: Badan Pusat Statistik, 2000-2015 (diolah)

\section{Ekspor Karet Indonesia}

Gambar di bawah ini menunjukkan perkembangan ekspor karet Indonesia dalam bentuk rempah (ribu ton) tahun 2000-2014.

\section{Gambar 2. Ekspor Karet Indonesia dalam Bentuk Rempah (ribu ton) Tahun 2000-2014}

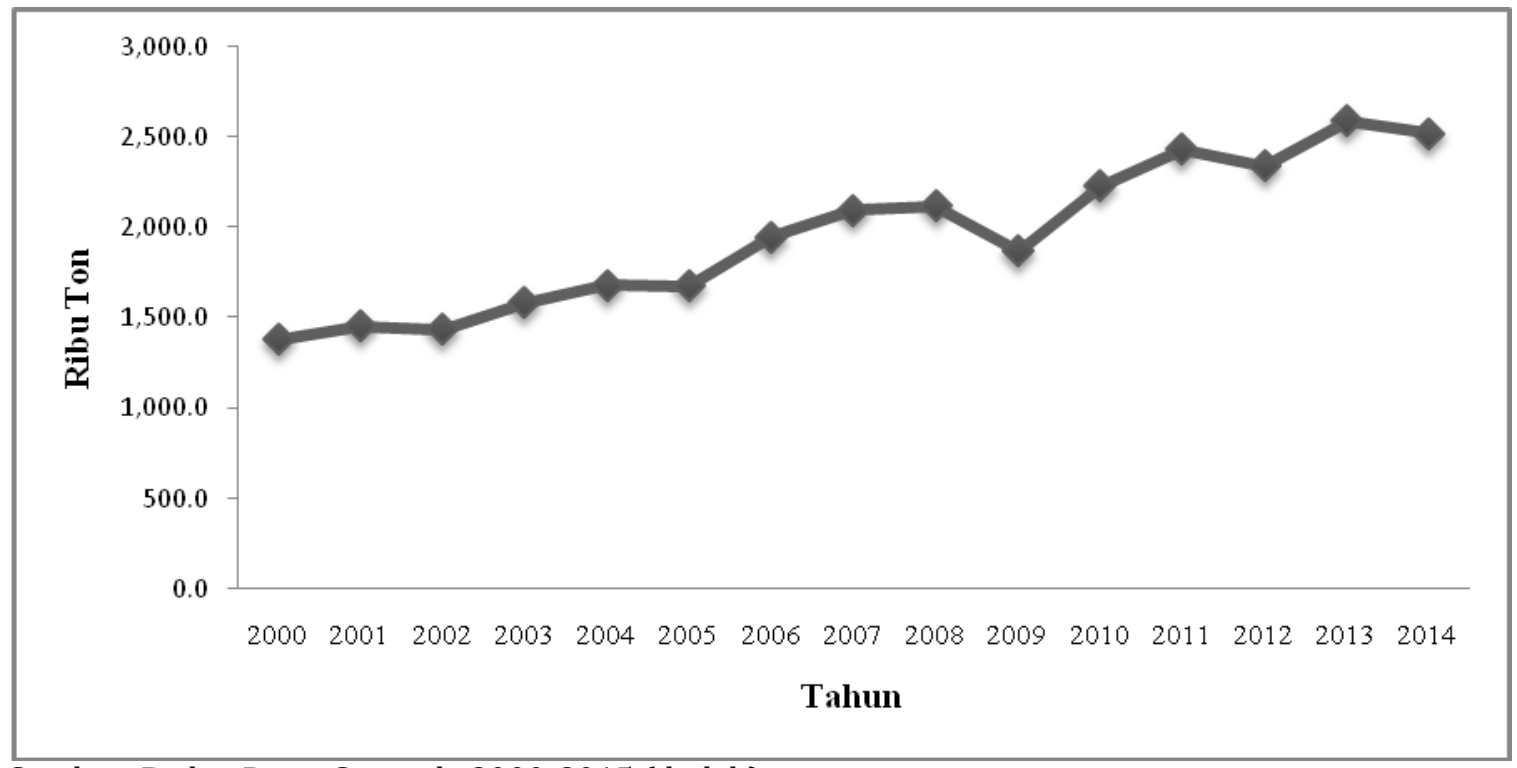

Sumber: Badan Pusat Statistik, 2000-2015 (diolah)

Produksi karet Indonesia tidak hanya digunakan dalam memenuhi kebutuhan konsumsi dalam negeri. Kelebihan permintaan dalam negeri mendorong dilakukannya ekspor ke luar negeri. Peningkatan ekspor berdampak pada peningkatan devisa. Peningkatan ekspor karet Indonesia seiring dengan semakin tingginya produksi karet yang dihasilkan (gambar 2). Beberapa negara tujuan potensial ekspor karet Indonesia selama ini diantaranya adalah negara Amerika Serikat, Jepang, dan Tiongkok. Kondisi perekonomian dunia dan negara tujuan turut mempengaruhi ekspor karet Indonesia. Beberapa bulan terakhir, harga karet kembali mengalami penurunan. Hal ini menimbulkan damak pada penurunan kesejahteraan petani karet. Jika kondisi yang semakin tidak menentu dan kurang menjanjikan ini berlangsung dalam waktu yang relatif lama, dapat berdampak pada penurunan produksi karet dalam negeri. 


\section{Hasil Pengolahan Data}

Data volume ekspor dan produksi karet Indonesia diolah dengan menggunkan bantuan program Eviews. Sebelum diperoleh Model Koyck, terlebih dahulu dilakukan pengujian asumsi klasik OLS yaitu uji normalitas, uji linieritas, uji heteroskedastisitas, serial korelasi dan multikolinieritas. Hasil pengujian ini ditunjukkan pada tabel 1.

Tabel 1. Hasil Pengujian Asumsi Klasik OLS

\begin{tabular}{|c|c|c|c|c|}
\hline Pengujian & Indikator & Nilai & Probabilitas & Keterangan \\
\hline Normalitas & Jarque-Bera & 0.67 & 0,72 & Data terdistribusi secara normal \\
\hline Linieritas & F-Statistic & 1.28 & 0.28 & Model Linier \\
\hline Heteroskedastisitas & Obs*R-squared & 3.60 & 0.61 & Tidak ada Heteroskedastisitas \\
\hline $\begin{array}{l}\text { Breusch-Godfrey Serial } \\
\text { Correlation LM Test: }\end{array}$ & Obs*R-squared & 3.18 & 0.20 & Tidak ada Serial Korelasi \\
\hline Pengujian & Indikator & Koefisien & Perbandingan & Keterangan \\
\hline Multikolinieritas & $\begin{array}{l}\mathrm{R}^{2}{ }_{1} \\
\mathrm{R}^{2}{ }_{11} \\
\mathrm{R}^{2}{ }_{12}\end{array}$ & $\begin{array}{c}0.0097 \\
-0.1205 \\
0.0002\end{array}$ & $\mathrm{R}^{2}{ }_{1}>\mathrm{R}^{2}{ }_{11}, \mathrm{R}^{2}{ }_{12}$ & $\begin{array}{c}\text { Tidak ada masalah } \\
\text { multikolinieritas }\end{array}$ \\
\hline
\end{tabular}

Sumber: Data Diolah Tahun 2015

Keterangan: $\mathrm{R}^{2}{ }_{1}$ adalah koefisien determinasi Model Koyck, $\mathrm{R}^{2}{ }_{11}$ adalah koefisien determinasi model dengan variable produksi karet tahun ini dan variable bebas ekspor karet tahun sebelumnya, $\mathrm{R}^{2} 12$ adalah koefisien determinasi model dengan variable terikat ekspor karet tahun sebelumnya dan variable bebas produksi karet tahun ini.

Tabel 1 menunjukkan bahwa hasil pengujian asumsi klasik OLS terpenuhi. Dari pengujian tersebut diketahui bahwa data terdistribusi secara normal, model linier, tidak ada heteroskedastisitas, tidak ada serial korelasi dan tidak ada masalah multikolinieritas. Selanjutnya dilakukan estimasi pengaruh produksi karet dalam negeri terhadap volume ekspor. Hasil estimasi Model Koyck dengan menggunakan metode OLS menghasilkan koefisien regresi $\mu, \beta_{0}$, dan $\lambda$ sebagaimana ditunjukkan pada tabel 2. Diperoleh nilai koefisien korelasi sebesar 0,93. Hal ini menunjukkan bahwa hubungan antara produksi karet dalam negeri dan volume ekspor karet pada periode yang diteliti adalah sangat tinggi. Hasil ini menunjukkan bahwa hubungan keduanya dapat dipelajari dengan menggunakan Koyck model. Dari output regresi Model Koyck (tabel 2), selanjutnya dapat disusun persamaan sebagai berikut:

$\mathrm{Q}_{\mathrm{t}}=120.94+0.61 \mathrm{P}_{\mathrm{t}}+0.33 \mathrm{Q}_{\mathrm{t}-1}$

Tabel 2. Output Regresi Model Koyck

\begin{tabular}{|c|c|c|}
\hline Variabel & Koefisien & Probabilitas \\
\hline $\mathrm{C}$ & 120.9443 & 0.4582 \\
\hline$P_{t}$ & 0.614898 & 0.0024 \\
\hline $\mathrm{Q}_{\mathrm{t}-1}$ & 0.329537 & 0.0750 \\
\hline R-squared & 0.931472 & \\
\hline Adjusted R-squared & 0.919012 & \\
\hline F-statistic & 74.75863 & \\
\hline Prob(F-statistic) & 0.000000 & \\
\hline
\end{tabular}

Sumber: Data Diolah Tahun 2015 
Penentuan lag didasarkan pada Schwarz criterion (SC) dengan nilai terendah. Tabel 3 menunjukkan nilai Schwarz criterion (SC) pada masing-masing lag. Sedangkan hasil distributed lag models ditunjukkan pada tabel 4.

Tabel 3 Nilai Panjang Lag Berdasarkan pada Schwarz criterion (SC)

\begin{tabular}{|c|c|}
\hline Lag Length & Schwarz criterion \\
\hline $\mathrm{K}=1$ & 12.56451 \\
$\mathrm{~K}=2$ & 12.42238 \\
$\mathrm{~K}=3$ & 11.97181 \\
$\mathrm{~K}=\mathbf{4}$ & $\mathbf{1 0 . 8 6 7 2 3}$ \\
$\mathrm{K}=5$ & 10.98802 \\
$\mathrm{~K}=6$ & 13.74040 \\
\hline
\end{tabular}

Sumber: Data Diolah Tahun 2015

Tabel 4 Hasil distributed lag models

\begin{tabular}{|c|c|c|c|c|c|c|}
\hline \multicolumn{7}{|c|}{$Q_{t}=-227.1231+1.013786 P_{t}-0.068463 P_{t-1}-0.132381 P_{t-2}+0.284428 P_{t-3}+0.008240 P_{t-4}$} \\
\hline \multicolumn{7}{|c|}{ Lag Length } \\
\hline & Constant & $\mathrm{t}$ & $t-1$ & $\mathrm{t}-2$ & $t-3$ & $\mathrm{t}-4$ \\
\hline Coefficient & -227.1231 & 1.013786 & -0.068463 & -0.132381 & 0.284428 & 0.008240 \\
\hline $\mathrm{t}$ - values & -2.168629 & 10.34366 & -0.552283 & -1.206702 & 4.220570 & 0.148161 \\
\hline Probability & 0.0823 & 0.0001 & 0.6045 & 0.2815 & 0.0083 & 0.8880 \\
\hline \multicolumn{7}{|c|}{$\mathrm{F}=110.88 \quad \mathrm{p}=0.000041$} \\
\hline
\end{tabular}

Sumber: Data Diolah Tahun 2015

Tabel 5 Hasil Model Koyck

\begin{tabular}{|c|c|c|c|}
\hline \multicolumn{4}{|c|}{$Q_{t}=120.9443+0.614898 P_{t}+0.329537 Q_{t-1}$} \\
\hline \multicolumn{4}{|c|}{ Lag Length } \\
\hline & Constant & $\mathrm{P}_{\mathrm{t}}$ & $\mathrm{Q}_{\mathrm{t}-1}$ \\
\hline Coefficient & $(\alpha) 120.9443$ & ( $\beta$ ) 0.614898 & $(\lambda) 0.329537$ \\
\hline $\mathrm{t}$-values & 0.768865 & 3.922704 & 1.966029 \\
\hline Probability & 0.4582 & 0.0024 & 0.0750 \\
\hline $\mathrm{R}^{2}=0.93 \quad \mathrm{~F}=74.76 \quad \mathrm{p}=0.000$ & & & \\
\hline $\begin{array}{l}\text { Average lag number } \\
\text { Average lag length } \\
\lambda / 1(1-\lambda)=0.329537 / 1(1-0.3\end{array}$ & & & \\
\hline
\end{tabular}

Sumber: Data Diolah Tahun 2015

Keterangan: $\mathrm{Q}_{\mathrm{t}}$ adalah volume ekspor karet di periode $\mathrm{t}, \mathrm{P}_{\mathrm{t}}$ adalah produksi karet dalam negeri di periode $\mathrm{t}$, dan $\mathrm{Q}_{\mathrm{t}-1}$ adalah volume ekspor karet dalam satu periode lebih awal dari t.

Koefieien $\beta_{0}$ dan $\lambda$ yang signifikan menjadi dasar bagi penghitungan $\beta_{1}, \beta_{2}, \beta_{3}$, dan $\beta_{4}$ adalah sebagai berikut:

$$
\begin{aligned}
& \lambda=0.329537 \\
& \beta_{0}=0.614898 \\
& \beta_{\mathrm{k}}=\lambda^{\mathrm{k}} \beta_{0} \\
& \beta_{0}=\lambda^{0} \beta_{0}=(0.329537)^{0}(0.614898)=0.614898 \\
& \beta_{1}=\lambda^{1} \beta_{0}=(0.329537)^{1}(0.614898)=0.202631 \\
& \beta_{2}=\lambda^{2} \beta_{0}=(0.329537)^{2}(0.614898)=0.066774 \\
& \beta_{3}=\lambda^{3} \beta_{0}=(0.329537)^{3}(0.614898)=0.022004 \\
& \beta_{4}=\lambda^{4} \beta_{0}=(0.329537)^{4}(0.614898)=0.007251 \\
& \left.\alpha_{0}=\alpha / 1-\lambda\right)=120.9443 / 1-(0.329537)=180.389
\end{aligned}
$$

Berdasar hasil perhitungan di atas, Model Koyck dapat ditulis ulang dengan persamaan sebagai berikut: $\mathrm{Q}_{\mathrm{t}}=180.389+0.614898 \mathrm{P}_{\mathrm{t}}+0.202631 \mathrm{P}_{\mathrm{t}-1}+0.066774 \mathrm{P}_{\mathrm{t}-2}+0.022004 \mathrm{P}_{\mathrm{t}-3}+0.007251 \mathrm{P}_{\mathrm{t}-4}$

Dari persamaan di atas, dapat dijelaskan bahwa:

1) Kenaikan satu ton produksi karet dalam negeri tahun ini akan meningkatkan volume ekspor karet sebesar 0.614898 ton. 
2) Kenaikan satu ton produksi karet dalam negeri satu tahun sebelumnya akan meningkatkan volume ekspor karet sebesar 0.202631 ton.

3) Kenaikan satu ton produksi karet dalam negeri dua tahun sebelumnya akan meningkatkan volume ekspor karet sebesar 0.066774 ton.

4) Kenaikan satu ton produksi karet dalam negeri tiga tahun sebelumnya akan meningkatkan volume ekspor karet sebesar 0.022004 ton.

5) Kenaikan satu ton produksi karet dalam negeri empat tahun sebelumnya akan meningkatkan volume ekspor karet sebesar 0.007251 ton.

Meskipun perubahan nilai lag dari produksi karet dalam negeri memiliki pengaruh positif pada volume ekspor, namun pengaruh ini semakin kecil.

\section{KESIMPULAN}

Berdasar hasil penelitian dan pembahasan yang telah diuraikan di atas, maka penulis dapat menarik kesimpulan bahwa selama periode pengamatan tahun 2000-2014, hubungan antara produksi karet dalam negeri dengan volume ekspor karet di Indonesia sangat tinggi yaitu sebesar 93\%. Koefisien ini menunjukkan bahwa Model Koyck sesuai untuk mempelajari hubungan antara jumlah produksi karet dalam negeri dan volume ekspor karet Indonesia. Dengan menggunakan Schwarz criterion (SC) diperoleh panjang lag adalah 4. Ini berarti bahwa voloume ekspor karet Indonesia dipengaruhi oleh produksi karet dalam negeri dalam kurun waktu empat tahun terakhir. Di sisi lain, menurut Model Koyck, waktu yang dibutuhkan untuk perubahan produksi karet dalam negeri memiliki efek yang signifikan dan terdeteksi pada volume ekspor yaitu 0,5 tahun. Selama periode pengamatan, kenaikan satu ton produksi karet dalam negeri tahun ini akan meningkatkan volume ekspor karet sebesar 0.614898 ton, kenaikan satu ton produksi karet dalam negeri satu tahun sebelumnya akan meningkatkan volume ekspor karet sebesar 0.202631 ton, kenaikan satu ton produksi karet dalam negeri dua tahun sebelumnya akan meningkatkan volume ekspor karet sebesar 0.066774 ton, kenaikan satu ton produksi karet dalam negeri tiga tahun sebelumnya akan meningkatkan volume ekspor karet sebesar 0.022004 ton dan kenaikan satu ton produksi karet dalam negeri empat tahun sebelumnya akan meningkatkan volume ekspor karet sebesar 0.007251 ton.

Karet merupakan salah satu komoditi perkebunan yang memberikan pengaruh yang besar dalam perekonomian Indonesia, hal tersebut ditunjukkan dengan kontribusi dalam Produk Domestik Bruto, disisi lain sektor ini merupakan salah satu sub sektor yang menyerap tenaga kerja yang tinggi. Untuk itu perhatian pemerintah sangat diperlukan dalam pengembangan produksi karet Indonesia. Hal yang tidak kalah penting adalah adanya stabilitas harga karet. Penurunan harga karet di tingkat petani berdampak pada penurunan daya beli dan kesejahteraan petani. Jika kondisi ini berlangsung dalam jangka waktu yang lama, terdapat kemungkinan akan terjadi penurunan produksi karet dalam negeri. Selain stabilisasi dan peningkatan harga karet, pengembangan industri pengolahan karet perlu ditingkatkan.

\section{DAFTAR PUSTAKA}

Badan Pusat Statistik. (2015). Statistik Indonesia 2015. Katalog BPS: 11010011. Jakarta: BPS Jakarta Indonesia.

Deliarnov. (1995). Pengantar Ekonomi Makro. Jakarta: UI-Press.

Gujarati, Damodar N. (1988). "Basic Econometrics Thrid Edition". McRaw-Hill International Book Company. United States Military Academy: West Point.

Lains, Alfian. (2006). Ekonometrika II: Teori dan Aplikasi. Jakarta: Pustaka LP3ES Indonesia.

Nachrowi, Usman. (2005). Penggunaan Teknik Ekonometri. Jakarta: PT RajaGrafindo Persada.

Ravines, Schmidt, Migon. (2003). "Revisiting Distributed Lag Models Through a Bayesian Perspective". (http://www.sbe.org.br/ebe25/140.pdf).

Setyawati, Intan Kartika. Lin, Yoeng-Shenn. Setiawan, Budi. (2014). Analisis Permintaan Ekspor Karet Alam Indonesia Ke Amerika Serikat. AGRISE Volume XIV No. 2 Bulan Mei 2014 ISSN: 1412-1425. 
Siburian, Onike. (2012). Analisis Faktor-Faktor Yang Mempengaruhi Ekspor Karet Alam Indonesia ke Singapura tahun 1980-2010. Universitas Negeri Semarang: Economics Develompent Analysis Journal 1 (2) (2012) ISSN: 2252-6560.

Sukirno, Sadono. (2011). Makroekonomi Teori Pengantar. Jakarta: PT Raja Grafindo Persada.

(2012). Mikroekonomi Teori Pengantar. Jakarta: PT Raja Grafindo Persada. 